\title{
Study on the Teaching of Mechanical Drawing for Supply-side Reform
}

\author{
Guijian Xiao*, Fei Liu, Chaosheng Song, Mingkim LIM, Qimin Li, Congbo Li \\ College of Mechanical and Vehicle Engineering, Chongqing University \\ ${ }^{*}$ Corresponding author. Email: xiaoguijian@cqu.edu.cn
}

\begin{abstract}
In the report of the 19th national congress of the communist party of China, it was mentioned that the supply side can promote the development and reform of the economy and improve the factors of production. Similarly, supply side also applies to the concept of drawing teaching to understand the needs of the students. Engineering for enterprise, in combination with intelligent manufacturing industry background, improves the ability of students through the innovation of teaching methods, which let students master the knowledge of mechanical drawing quickly, and promote its application in actual, skilled engineering and in the enterprise.
\end{abstract}

Keywords: Supply side, Intelligent manufacturing, Mechanical drawing.

\section{INTRODUCTION}

A compulsory important basic course is Mechanical Drawing for mechanical engineering. Mechanical drawing course mainly focuses on the basic principle of mechanical design drawings, the method and drawing related national standards system. Its goal is to cultivate students' basic ability of drawing and reading engineering drawing, master the application ruler gauge drawing, freehand drawing and computer drawing skills, and improve the students' ability of space imagination, space thinking and innovative thinking [1]. Moreover, it can help to clarify the mechanism of the learning process, understand the characteristics of selforganizing learning in the process of physiology and practice, and explore the basic elements of improving students' learning ability on this basis, and comprehensively use various educational means to activate and enhance students' learning ability.

With the implementation of the development strategy of intelligent manufacturing in China, various scientific research institutes and intelligent manufacturing enterprises need a large number of mechanical engineering professionals in intelligent manufacturing, so the specialized course of mechanical drawing is particularly important. As a compulsory basic professional course for undergraduate students of science and engineering in colleges and universities, mechanical drawing is one of the first courses that students come into contact with. The organization and arrangement of its teaching activities not only directly affect students' learning effect of this course, but also have an important impact on the interest cultivation of subsequent professional knowledge learning [2]. The traditional teaching method is too boring to stimulate students' interest in learning. It is possible to stimulate students' potential, improve their comprehensive ability, and cultivate innovative and creative talents with comprehensive development of engineering ability under the background of intelligent manufacturing development.

\section{THE CURRENT SITUATION AND PROBLEMS OF MECHANICAL DRAWING TEACHING}

\subsection{Teaching Status}

In recent years, the teaching method and content had the very big change, from the traditional blackboard freehand drawing teaching to giving priority to multimedia teaching blackboard writing as the auxiliary teaching. The teaching effect had the very big enhancement, but the teaching pattern is still not changed. There are still a lot of problems. Students passively accept knowledge cramming education mode, master the knowledge and stay on the book, ignore the cultivation of innovation ability and practice of the application of knowledge [3]. For example, mechanical students have finished this course with excellent results, but when they finish their graduation design or 
participate in the competition, they still make many mistakes in the design and expression of parts, drawing of parts and assembly drawings, and marking of dimensions and tolerances.

The importance of theory teaching is ignored. In the actual course schedule of mechanical drawing, the teaching time of theory takes up most of the time, while the proportion of practical teaching is often very small. However, in fact, classroom theoretical teaching can only enable students to learn knowledge passively. Letting students master knowledge, the use of knowledge in the practical teaching related to actual engineering problems is necessary. Therefore, in the course of mechanical drawing teaching, we should strengthen the ability of application and engineering innovation thinking ability.

\subsection{Problems}

Lack of practical case system training, textbook knowledge of each chapter is relatively independent. The content of each chapter in the course of mechanical principles is relatively independent, and there is no corresponding practical case. Students can only learn basic knowledge and have no opportunities to apply the knowledge to solve practical engineering problems.

Lack of effective and comprehensive teaching evaluation system, in terms of teaching effect evaluation, the system is not perfect and lacks comprehensive and

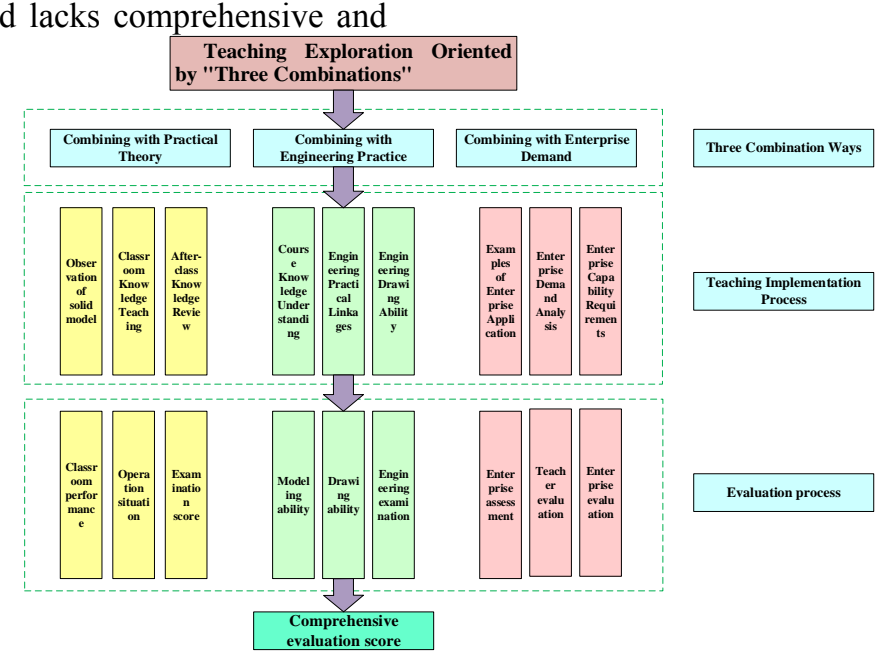

Figure 1 Teaching mode oriented by "three combinations".

\subsection{Combination of Curriculum and Practical Theory}

Mechanical drawing is the core of adaptive ability; this course has long been more emphasis on the process of teaching students to adapt to the teachers' teaching. Therefore, it is necessary to combine the course content with practical theories to improve students' charting ability. quantitative evaluation indexes for learning process. At present, the main assessment indicators are classroom attendance, homework and final exam, which to some extent make students pursue only the final score and ignore the importance of process learning. In addition, there is no corresponding learning module and assessment index in assessing the improvement of students' ability.

\section{THE TEACHING INQUIRY GUIDED BY "THREE COMBINATIONS"}

When the teacher teaches, he often reads according to the textbook, and the book knowledge is very boring. If the teacher keeps teaching according to the book, the students will soon lose interest in this course[4]. In the specific teaching process of mechanical drawing, it is necessary to fundamentally and effectively ensure the effective connection and comprehensive integration between the taught course content and the specific practical application in the actual teaching activities of mechanical drawing. Therefore, this paper puts forward a teaching mode which is oriented by the combination of three aspects and combines with practical theories to consolidate professional knowledge better. To better understand the purpose of teaching in combination with the needs of enterprises. According to the requirements, a three-combination-oriented teaching model is formed, as shown in the figure 1 below. 


\subsection{Combination of Courses and Engineering Practice}

In the process of teaching, we should always uphold the teaching model of learning. Let the taught knowledge can be applied in engineering, in turn, students are required to learn the introduction to engineering drawing, to be able to draw engineering drawing and meet the requirements of engineering drawing.

In the process of class, students can not only learn the contents of textbooks or textbooks, but also relevant contents from multiple perspectives. In combination with practical theories, students can better adapt to various requirements in engineering through the teaching method of engineering training.

In the actual mechanical drawing teaching activities, to ensure that in the actual engineering application and relevant practice as the basic demand, and the project learning method more effectively use advanced teaching concept, and fully integrated in the process of teaching, for mechanical parts the design characteristic, the concrete application and the principle of intensive analysis and exploration, fundamentally solve the concrete requirements in design, actively cultivate highquality skilled practical mechanical drawing talents.

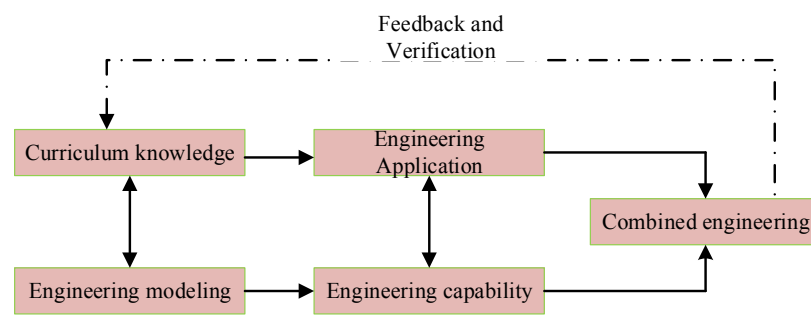

Figure 3 Combination of courses and engineering.

\subsection{Combination of Curriculum and Enterprise Needs}

However, in order to avoid the teaching method combining curriculum with enterprise requirements being turned into a paper form, the teacher must clarify the specific application steps of the teaching method combining curriculum with enterprise requirements, so that the teacher can gradually guide students to complete the teaching of relevant teaching content.

Firstly, we should make clear the teaching tasks of the course. Secondly, students should be guided to reasonably develop the connection between knowledge points of the course and engineering practice according to their own learning situation. Finally, the evaluation work after the implementation should be done. This step is mainly to effectively test the actual results of the implementation of the project, so as to find out the reasons for the differences in the implementation of the project, so as to better guide the implementation of the teaching work and comprehensively ensure the quality of the course teaching.

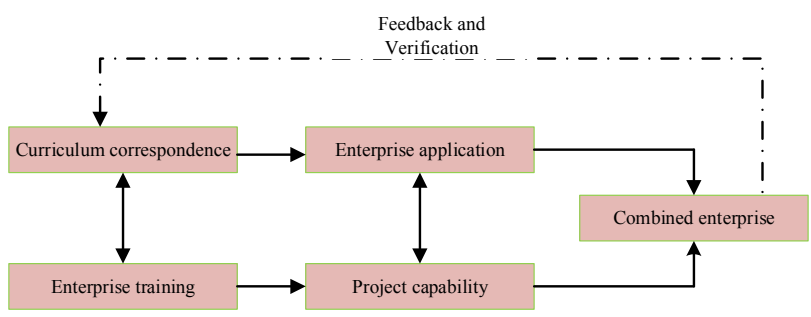

Figure 4 Courses align with business needs.

\section{EVALUATION INDEX OF TEACHING MODE}

In fact, the evaluation of students' learning effect of mechanical drawing course should not only focus on their understanding and mastery of knowledge and skills, but also pay attention to their ability improvement in participating in practical projects. Not only pay attention to the results of students' study assessment, but also pay attention to their performance in the learning process. Therefore, the teaching evaluation system proposed in this paper adopts diversified evaluation forms, combines process evaluation with result evaluation, divides course according to different importance, and includes students' self-evaluation to comprehensively give students' final scores. Based on the above requirements, a teaching evaluation method based on the overall process is proposed, as shown in table 1.

Traditional teaching evaluation feedback is usually conducted in the form of paper questionnaires. Because manual statistics are needed, it will take a certain amount of time and manpower [5]. And in today's information, age provides us with a more concise and convenient questionnaire form. We can create a questionnaire, automatically generate qr code on the website, and students can scan qr code by mobile phones into the mobile terminal interface to fill in the questionnaire and submit, teachers can be real-time in the background to see the questionnaire results. the software can automatically analyze the questionnaire results, find on what problem students focus, which is easy to mastered by the teachers and help to know the students' understanding of knowledge, the way of evaluation and enhance the effectiveness of teaching evaluation and statistics.

In a word, the application of "Three combination" oriented teaching method in "mechanical drawing" can give full play to the guiding role of teachers and students' self-learning initiative, and truly enable students to "learn by doing" and "learn by doing", which is conducive to improving the effectiveness of course teaching. Therefore, in the actual course teaching of mechanical drawing, teachers need to take students as the teaching center to reasonably plan the course 
teaching steps, so as to give full play to the positive role in improving the course teaching. of the teaching method oriented by "three combinations"

Table 1. Curriculum evaluation system based on overall process

\begin{tabular}{|c|c|c|c|c|c|}
\hline \multirow{2}{*}{$\begin{array}{l}\text { Evaluation of } \\
\text { project }\end{array}$} & \multirow{2}{*}{$\begin{array}{l}\text { Level } 1 \\
\text { The } \\
\text { weight }\end{array}$} & \multirow{2}{*}{$\begin{array}{c}\text { Evaluation } \\
\text { index/secondary weight }\end{array}$} & \multicolumn{2}{|c|}{$\begin{array}{c}\text { Evaluator/secondary } \\
\text { weight }\end{array}$} & \multirow[t]{2}{*}{ Evaluation method } \\
\hline & & & Teachers' & classmate & \\
\hline attendance & $5 \%$ & / & $100 \%$ & $0 \%$ & 1 \\
\hline homework & $10 \%$ & $\begin{array}{l}\text { (1) normative } / 40 \% \text {; } \\
\text { (2) correctness } / 60 \%\end{array}$ & $100 \%$ & $0 \%$ & $\begin{array}{c}\Sigma \text { (single homework) present } \\
\text { work times } 10 \% \times\end{array}$ \\
\hline $\begin{array}{c}\text { Class } \\
\text { discussion }\end{array}$ & $10 \%$ & $\begin{array}{l}\text { (1) group discussion results } \\
/ 40 \% \text {;(2) group results } \\
\text { display } / 40 \% \\
\text { (3) participation } / 20 \%\end{array}$ & $70 \%$ & $30 \%$ & $\begin{array}{c}\Sigma(\text { single discussion grade } \\
\text { teachers } 70 \%+\text { single discussion } \\
\text { students rate } 30 \%) \text { present task } \\
\text { frequency by } 10 \% \times \times \times\end{array}$ \\
\hline $\begin{array}{l}\text { Company } \\
\text { internship }\end{array}$ & $10 \%$ & $\begin{array}{l}\text { (1) internship attendance } \\
/ 20 \% ;(2) \text { enterprise } \\
\text { engineer evaluation } / 80 \%\end{array}$ & $70 \%$ & $30 \%$ & $\begin{array}{l}\text { (teachers grade } 70 \%+\text { students } \\
\text { grade } 30 \% \text { ) } 5 \% \times \times \times\end{array}$ \\
\hline $\begin{array}{l}\text { The } \\
\text { engineering } \\
\text { practice }\end{array}$ & $10 \%$ & $\begin{array}{l}\text { (1) engineering practice } \\
\text { works } / 40 \% \\
\text { (2) practice report } / 30 \% \\
\text { (3) division of tasks } / 30 \%\end{array}$ & $70 \%$ & $30 \%$ & $\begin{array}{l}\text { (teachers grade } 70 \%+\text { students } \\
\text { grade } 30 \%) 10 \% \times \times \times\end{array}$ \\
\hline $\begin{array}{l}\text { Curriculum } \\
\text { design }\end{array}$ & $15 \%$ & $\begin{array}{l}\text { (1) curriculum design } \\
\text { works } / 40 \% \\
\text { (2) course design defense } \\
130 \% \\
\text { (3) division of tasks } / 30 \%\end{array}$ & $70 \%$ & $30 \%$ & $\begin{array}{l}\text { (teachers grade } 70 \%+\text { students } \\
\text { grade } 30 \% \text { ) } 15 \% \times \times \times\end{array}$ \\
\hline Test scores & $40 \%$ & / & $100 \%$ & $0 \%$ & l \\
\hline
\end{tabular}

\section{CONCLUSION}

With the innovation of teaching method of "three combination" and the establishment of multi-teaching evaluation system, students have a deeper understanding of mechanical drawing, and realize a more systematic and comprehensive mechanical discipline while studying this course. At the same time, compared with the previous non-innovative teaching methods, students' performance has been greatly improved, with the passing rate rising to $99 \%$, and the proportion of students with more than 90 scores reaching 30\%. It shows that this innovative teaching method has positive effects on students.

\section{ACKNOWLEDGMENTS}

Formative education research on the professional knowledge structure of mechanical engineering with a large-scale engineering vision (193015), research on the reform and practice of personnel training of robot engineering under the background of new engineering (191001) and research and practice of supply side reform in the training of first-class mechanical engineering professionals (181016).

\section{REFERENCES}

[1] X.W. Zheng, Z.H. Zhu, J. Yuan. Discussion on teaching methods and methods of mechanical drawing [J]. University education, 2019(06): 68-70.

[2] D.H. Dai. Application of three-dimensional software and micro-lesson in the teaching of mechanical drawing in secondary vocational school -- a case study of three-view teaching $[\mathrm{J}]$. Hubei agricultural mechanization, 2019(09): 39.

[3] G.L. Sun. Teaching reform of mechanical drawing and training of practical talents $[\mathrm{J}]$. Wind of science and technology, 2019(13): 48.

[4] X.Y. Hao, F.Y. Wang. Teaching reform of electromechanical transmission control course based on ability orientation [J]. University laboratory work research, 2016, 4:37-38.

[5] Wang jia. Brief analysis of information teaching and its application in the course of "mechanical drawing" in secondary vocational schools [J]. Journal of Tianjin vocational colleges, 2019, 21(03): 60-64. 